\title{
CORPORATE BONDS, MACROECONOMIC NEWS AND INVESTOR FLOWS
}

\author{
Arjun Chatrath \\ Hong Miao \\ Sanjay Ramchander \\ Sriram Villupuram
}

\begin{abstract}
:
We examine the impact of macro-economic announcements on corporate bond prices and investor migrations within various types of bonds across time. In addition we also compare the effects on yields of investor grade bonds vs. speculative within corporate bonds. We estimate macro-economic shock related to each macro-announcement based on market expectations. First, we find that the corporate bonds behave differently to macro shocks than treasuries. Second, we identify that the sensitivity of junk bonds to shocks is much more pronounced than that for investment grade bonds. Positive macro shocks lead to decrease of yields on corporate bonds and increase of yields in treasury bonds, which could imply that investors are migrating from treasuries to corporate bonds. Also, we conclude that the behavior of corporate bonds is very similar to that if their equity counterparts in that they are more sensitive to negative macro shocks than to positive shocks.
\end{abstract}




\section{CORPORATE BONDS, MACROECONOMIC NEWS AND INVESTOR FLOWS}

This paper is an empirical study of the impact of macroeconomic news releases on corporate bonds. There is an extensive literature that documents the relevance of macro information on diverse asset classes such as equities, Treasuries, currencies and commodities. Broadly speaking, these studies seek to verify various theories related to price discovery, price formation and market efficiency, and provide implications on asset pricing models and portfolio formation. However, empirical applications of these issues are only just beginning to emerge in the corporate bond literature, with a focus on the behavior of liquidity and price transparency. For example, Bao, Pan and Wang (2009) evaluate the liquidity properties in the corporate bond market and document significant levels of illiquidity in this market that is both time varying and related to bond specific characteristics. Huang and Huang (2003) find that credit risk accounts only for a small portion of the corporate bond-Treasury yield spreads thus leaving open the role of illiquidity in contributing to the unexplained portion of yield spreads.

The lack of adequate empirical research in corporate bonds is quite remarkable given the size of this market, which is larger than the market for U.S. government or municipal bonds, and its role in serving as a key source of financing for businesses. ${ }^{1}$ The gap in research may be attributed to the opacity of trading prices in corporate bonds compared to other markets. Unlike equity markets that disseminate continuous pre-trade and post-trade information, corporate bonds trade primarily over-the-counter (OTC), and until recently, lacked a centralized system of collecting and reporting secondary market transactions information. Public dissemination of

\footnotetext{
${ }^{1}$ According to the Bank of International Settlements, the total outstanding amount of corporate bonds in the U.S. at year 2004 was about $\$ 15.1$ trillion.
} 
investment grade security prices began with the introduction of the Trade Reporting and Compliance Engine (TRACE) system in July 1, 2002, ${ }^{2}$ and the coverage was later expanded in February 2005 to include almost all public transactions. The introduction of TRACE provides researchers a new avenue to explore the pricing and trading behavior of an important market segment that has largely escaped the kind of scrutiny that equities markets attract. Bessembinder et al. (2006) find that introduction of the TRACE transaction reporting system has resulted in a significant reduction of trade execution costs for institutional investors.

A significant contribution of our study is that we use transaction-level corporate bond data for the period 2005 through 2010 to address three important research questions. First, given that macro announcements convey new information about the economy, do corporate bond yields respond to such information in an economically meaningful manner? Asset prices are known to be sensitive to changes in investors' beliefs about the hidden states of fundamentals and expectations of future real economic growth. Therefore, from an asset substitution framework, one could posit that unexpected improvements in the economy would decrease demand for Treasury instruments in favor of riskier alternatives such as high-yielding corporate bonds, and therefore increase (reduce) corporate bond prices (yields). In a similar vein, unexpected increases in price levels may cause investors to shift out of safer corporate fixed income securities into stocks whose dividend streams are relatively more stable in real terms. Owing to the forwardlooking nature of asset prices, market participants often interpret yield or spread changes to be indicative of the degree of strain on financial markets.

\footnotetext{
${ }^{2}$ TRACE reporting initially applied to a group of 498 bonds with issuance size of $\$ 1$ billion or greater, and it required NASD member to report all corporate bond transactions to the TRACE system within 75 minutes of the transaction.
} 
Second, since yields on corporate securities are often benchmarked with Treasury yields, do economic announcements impact corporate bond yield spreads in some predictable manner? The contingent-claims framework posits that yield differences between corporate and Treasury securities provide an indication of the bond's default risk. Extending this argument further, Jarrow and Turnbull (2000) show that yield spreads contain forecasting ability on corporate defaults, thus suggesting that spreads contain information about common economic underlying variables. Philippon (2008) provide a theoretical framework in which the predictive content of corporate bond spreads for economic activity stem from their ability to reflect changes in corporate cash flows prior to cyclical inflection points. More recently, studies implicate several additional variables such as equity market risk (Collin-Dufresne et al., 2001), implied stock options volatility (Cremers et al., 2008), liquidity proxies (Chen et al., 2007), and interest rate factors (Hibbert, et al., 2011) in explaining yield spread movements. Given that economic state variables seem to underlie the observed relationship between yields spreads and various market factors, our study would document the nature and direction of influence of economic variables. In general, one would anticipate wider credit spreads to be associated with a deteriorating economy as investors move to a higher quality asset or expect offsetting monetary injections by the Fed.

Finally, related to the previous question, do speculative grade (or junk) bonds react differently than investment grade bonds? This is an open empirical question since the focus of most prior studies has been on investment grade bonds where data has been more easily available (see, for example, Campbell and Taksler, 2003). Market participants often interpret credit ratings, which are an evaluation of credit worthiness, to extract information about default 
probability. Therefore, because of its heightened sensitivity to default risk, we xpect the response of high-yield bonds spreads to be most pronounced to economic news.

\section{DATA AND SAMPLE SELECTION}

Corporate bonds price and trade data for the period 2005-2010 are obtained from the Financial Industry Regulatory Authority's (FINRA)'s TRACE corporate bond database. Compared to equities the corporate bond market is not very liquid. Panel A of Exhibit 1 reports a summary of all bonds reported in the TRACE corporate bond database during the period 20052010. We find that, on average, the number of transactions per bond in a given year varies from 214 in 2007 to 460 in 2009 . The average number of intraday transactions per bond is between 0.85 and 1.83. Strikingly, we notice that several bonds do not trade at all - on average, transactions occur only on $20 \%$ of trading days. For example, in 2010 , the average number of days that bonds traded was only 46.4 days. Therefore, given the illiquidity in bond markets, we decide to focus our analysis only on a subset of the most highly traded bonds. Specifically, bonds examined in the study are those that are listed by the TRACE annual fact book as the top fifty publicly traded corporate investment grade issues and the top fifty high-yield issues by number of trades executed in each year. All of the top fifty bonds have fixed rate payments, are nonconvertible, and do not carry any option type features. The fact book also provides information on original maturity, remaining life, credit rating, and coupon rate for each bond.

The analysis starts with all recorded intraday transactions of the top fifty sample bonds over the study period, and the transactions are then aggregated to daily observations. ${ }^{3}$ Panel B of Exhibit 1 presents a summary of all the top fifty liquid bonds from 2005 to 2010. It is clear, that

\footnotetext{
${ }^{3}$ Due to limited intraday transactions we chose to focus our analysis on daily prices.
} 
these representative bonds are significantly more liquid than the broader sample of bonds in the TRACE database, but still not liquid enough for an intraday study. The average numbers of intradaily transactions vary from 22.4 for high-yield bonds in 2007 to 84.7 for investment bonds in 2009. However, the average number of days with transactions for the top fifty bonds are between 214.8 (high-yield bond in 2009) and 250.2 (investment bond in 2008).

Exhibit 2 reports additional descriptive statistics. We compute a daily value-weighted average yield using the par amounts of each transaction as weights if there are multiple transactions for a given bond on a given date. Evidence from Panel A indicates that the raw data sample contains extreme outliers, such as the maximum yield of the junk bond group is $159,407 \%$ and the minimum yields for both bond types are zero. Furthermore, we observe that the mean yields of investment and the junk bonds are $5.28 \%$ and $23.91 \%$, respectively; whereas the corresponding medians are $5.21 \%$ and $8.88 \%$. This evidence combined with values from the $95^{\text {th }}$ and $99^{\text {th }}$ percentiles suggests that there are significant numbers of outliers in the yield series, particularly among high-yield bonds.

Panel A also provides information on yield spreads, calculated as the difference between the yield to maturity of the sample corporate bond and the interpolated yield-to-maturity of the Treasury yield curve corresponding to the corporate bond's time to maturity. To obtain the Treasury yield curve, we use the constant maturity Treasury bond indices of 1, 3 and 6 months, and the 1, 2, 3, 5, 7, 10, and 20 year from the Board of Governors of the Federal Reserve System website $^{4}$. We use cubic splines to obtain points on the Treasury yield curve for the corresponding bond maturities. For bonds with maturity beyond the available range, we use the endpoint

\footnotetext{
${ }^{4}$ The link is: http://www.federalreserve.gov/releases/h15/data.htm.
} 
Treasury yields. That is, for bonds with maturity less than a month, we use the one month constant maturity Treasury yield and for those with maturity longer than 20 years, the 20 year constant maturity Treasury yield is used. The mean yield spreads for investment and speculative grade bonds are $1.90 \%$ and $20.78 \%$, respectively.

The other variables whose statistics are presented in the Exhibit include price, volume, time to maturity (in years), modified duration and convexity. ${ }^{5}$ The daily price is the value-weighted average price weighted using par amounts of each transaction. Given that bond prices are an inverse measure of bond yields, we notice that the price ranges for the investment and high-yield bonds are $\$ 39.85$ to $\$ 343.59$, and $\$ 0.00$ to $\$ 230.16$ per $\$ 100$ face value, respectively. Time to maturities of the investment bonds is between 0.01 to 57.86 years with an average of 6.02 years, whereas the corresponding range for junk bonds is 0.01 to 40.12 years. The "N/A" $\mathrm{s}$ in the time to maturity statistics are caused by four bonds whose maturities were found to be missing. We notice that the average remaining life for the investment and high-yield bonds are 6.02 years and 6.13 years, respectively, and high-yield bonds have a smaller duration than investment bonds (3.76 versus 4.62 , respectively).

${ }^{5}$ The modified duration measures the price sensitivity of a bond and is the percentage change in price for a unit change in yield. It is calculated using the following equation:

$$
\text { Duration }=\frac{1}{P\left(1+\frac{y}{k}\right)} \sum_{i=1}^{n} t_{i} \frac{c_{i}}{\left(1+\frac{y}{k}\right)^{t_{i}}}
$$

where, $P$ is the bond price, $y$ is the yield-to-maturity, $k$ is the compounding frequency ( 2 for semi-annual), $c_{i}$ is the $i^{\text {th }}$ cash flow, $t_{i}$ is the time (in year, from today) of receiving the $i^{\text {th }}$ cash flow, $n$ is the total number of remaining cash-flows to be received. Convexity is a measure of the sensitivity of the bond's duration to changes in interest rates, and is calculated as:

$$
\text { Convexity }=\frac{1}{P\left(1+\frac{y}{k}\right)^{2}} \sum_{i=1}^{n} t_{i} \frac{c_{i}}{\left(1+\frac{y}{k}\right)^{t_{i}}}\left(t_{i}^{2}+t_{i}\right)
$$


In order to draw robust inferences from our study we remove: (a) daily observations of bonds with zero yields; (b) yields higher than 100\%; and (c) missing maturities. This yields a revised sample of 296 bonds. The descriptive characteristics are reported in Panel B of Exhibit 2. Notice that the average yield and yield spreads for junk bonds falls considerably to $11.89 \%$ and $8.57 \%$, respectively. The other descriptive variables in Panel B are relatively unchanged when compared to Panel A.

Our second data set comprises of macroeconomic news data. Bloomberg is the source for both pre-announcement consensus (median) forecasts and the realized value for each monthly, pre-scheduled macroeconomic news release. Each news release is "standardized" by dividing the difference between the realized value and the consensus forecast by its standard deviation. This allows us to compare the impact of the different macroeconomic news announcements. That is,

$$
S A_{i, t}=\frac{A_{i, t}-E_{i, t}}{\sigma_{i}}
$$

where $\mathrm{SA}_{\mathrm{i}, t}$ is the surprise element of the announcement of type $i$ at time $t, A_{i, t}$ is the realized or actual value of an announcement, $E_{i, t}$ is the consensus forecast and $\sigma_{i}$ is the sample standard deviation of the surprise component of the type $i$ announcement, $A_{i, t}-E_{i, t}$. The standardization procedure does not affect the statistical significance of the estimated response coefficients and the fit of the regression model discussed below, because $\sigma_{i}$ is constant for each announcement.

Exhibit 3 provides summary statistics of the 19 types of macroeconomic news surprises. Note, among the different news announcements, ten are released at 8:30 am, two at 9:15 am, five at 10:00 am, one at 2:00 pm, and one at 2:15 pm. ${ }^{6}$ The differences in the mean surprises and the

\footnotetext{
${ }^{6}$ All times are U.S. Eastern Standard Time (EST)
} 
standard deviations confirm that the data should be standardized in order to assess the impact of the different types of announcements. For example, the reported numbers for Unemployment Rate is a percentage and thus, the mean and standard deviation of the surprises are $0 \%$ and $0.0015 \%$, respectively, whereas the numbers for change in Nonfarm Payrolls are in thousands and thus the mean and standard deviation of the surprises are -13.6667 and 66.6115 , respectively. Therefore, the surprises are standardized in order to compare the different regression coefficients.

\section{EMPIRICAL RESULTS}

\section{Macroeconomic News and Bond Yields}

A preliminary analysis of the influence of macro announcements on yields is conducted by comparing the mean yields and mean yield spreads on news days (also referred as 'study sample') versus a matched control sample that is constructed from days when there are no macroeconomic news releases (or 'no-news sample'). The null hypothesis that the mean difference between the two samples is equal to zero is tested with a z-statistic given by: $z=\left(\bar{Y}_{S}-\bar{Y}_{C}\right) / \sqrt{\frac{s_{S}^{2}}{n_{S}}+\frac{s_{C}^{2}}{n_{C}}}$, where $\bar{Y}_{S}$ and $\bar{Y}_{C}$ are the yields in the study and control samples, $s_{S}$, and $s_{C}$, are standard deviations of corresponding yields, and $n_{S}$, and $n_{C}$, are the numbers of observations in the experimental and control samples. These results are reported in Exhibit 4.

Panel A provides results that are classified by the number of news events (aggregated across all news events) in a trading day. We notice that there are roughly an equal number of days in the sample period that comprise news and non-news days (752 and 760 days, respectively). Furthermore, on any given day, a large majority (specifically, 428 events or about 57\%) of news 
items appear as a standalone event. An additional 237 news announcements jointly occur with one other announcement on the same day. It is also clear that on most news announcement days, yields on both speculative and investment bonds are significantly larger than their associated benchmark yields of the control sample. For instance, the average yield on junk bonds on days with only one news announcement is about $12 \%$, compared to about $11.74 \%$ on no-news days. This difference is statistically significant at the $1 \%$ level. Similarly, with investment grade bonds, the yields are $5.46 \%$ versus $5.32 \%$ on news and no-news days respectively. Interestingly, there is no evidence of a consistent relationship between news and Treasury yields; however, the impact on yield spreads is clear and consequential. For both types of bonds, the yields spreads on news days are larger than the control sample.

Further insights are derived by separating news days into days that are unambiguously positive and negative depending on the sign of the economic news surprise. Positive and negative news days are defined as days when economic news are all positive and negative, respectively. We notice that the higher levels of yields and yield spreads on news days are primarily attributed to negative surprises. For example, we observe that the average yield spreads on negative news days is higher than non-news day for both high-yield bonds $(9.10 \%$ versus $8.40 \%)$ and investment bonds (2.06\% versus $1.99 \%)$. The differences are statistically significant at the $1 \%$ level of significance. On the other hand, the mean yields for positive news days are not statistically significant from the non-news days. The "mixed" days, when there are both positive and negative surprises, also see statistically higher means for both the high-yield bonds $(8.84 \%$ versus $8.40 \%$ ) and investment bonds (1.98\% versus $1.99 \%)$. 
Panel B of Exhibit 4 provides additional granularity into the relationship by examining results that are disaggregated by individual news type. Several interesting results are evident. First, as documented in Panel A, economic surprises generally correspond with larger corporate bond yields when compared to the control sample. Note the average yields on junk and investment bonds for the control (no-news) sample are $11.74 \%$ and $5.32 \%$, respectively. Specifically, we find 9 announcements that correspond with statistically significant and larger corporate yields than the means of the control sample. Five of these announcements - Business Inventories, FOMC, Industrial Production, Personal Income, and Unemployment Rate - are common for both speculative and investment bonds. Second, in the case of Treasury yields, the control sample has an average yield of 3.34\%. However, several announcements are found to be associated with yields that are lower than the control sample. For instance, the average Treasury yields corresponding to speculative and investment grade bonds on days with Personal Income announcements are $3.18 \%$ and $3.32 \%$. This is nearly 16 and 12 basis points, respectively, below the control sample yield. Third, in general, yield spreads for junk bonds are much larger than investment bonds on both news and non-news days. For the no-news sample, the spread for speculative bonds is about 4.5 times larger than the spread for investment bonds $(8.40 \%$ versus $1.88 \%)$. Notably, the same five news releases that are significantly related with corporate bond yields - Business Inventories, FOMC, Industrial Production, Personal Income, and Unemployment Rate - also register pronounced impact on both Treasury yields, and bond yield spreads. For example, on days with an FOMC surprise, the yield spread on speculative bonds is $19.95 \%$ compared to $3.74 \%$ for low-yield bonds. This is about $12 \%$ and $1.85 \%$, respectively, higher than the benchmark control sample yield spread. 
Exhibit 5 provides results sorted by positive and negative news values in Panels A and B, respectively. For purpose of exposition, all news variables with the exception of Unemployment Rate are treated as pro-cyclical indicators of the economy. In other words, positive surprises in these variables would represent stronger-than-expected economic growth, and negative values are indicative of weaker-than-expected economic growth. The sign of the unemployment rate is reversed in order to make it consistent with the other variables.

Reviewing the positive surprises in Panel A, the mean yields on speculative bonds for ten out of 19 announcement types are significantly different from the benchmark (no-news) yields. Notably, for eight of these announcements - Business Inventory, Capacity Utilization, Factory Orders, Housing Starts, PPI, NAPM, Nonfarm Payroll, Unemployment Rate - the mean yields are significantly less than the control sample. For instance, on days with better than expected Nonfarm Payroll, the average yield on speculative bonds is $10.85 \%$ which is about $0.88 \%$ lower than the benchmark yields. In contrast, the response of the Treasury yields that correspond to high-yield bonds is decidedly mixed. For 15 out of 19 types of announcements, the mean yields on days with positive economic news are significantly different from days without news. However, there is no clear relationship since eight of these announcements increase Treasury yields and the remaining seven decrease yields. The results for investment grade bonds are qualitatively similar - with the exception of Factory Orders and Housing Starts all other announcements that were influential in lowering speculative bond yields below their benchmark yields are also significant in the case of investment bonds. Overall, however, there is strong evidence that that yield spreads contract on days with better-than-expected economic news associated with several different types of announcements. 
An overview of results in Panel B indicate that days with negative surprises are associated with higher speculative and investment yields, generally lower Treasury yields, and wider yield spreads. There is a large degree of commonality among the announcements that are significant; however, what is interesting is that examining the magnitude of the yields negative news seems to elicit a larger response than positive news.

The findings in Exhibit 5 indicate that positive (negative) news is largely associated with lower (higher) corporate yields and yield spreads. These effects can be explained within the asset substitution framework which posits that an unexpected improvement in the economy increases investors' risk appetite leading them away from low risk Treasury bonds to riskier corporate securities. Conversely, in the presence of worse-than-expected economic news, investors shift away from risker securities into safe and liquid markets, particularly U.S. Treasury securities. The effects of "flight to risk" or "flight to safety" shifts in portfolio composition are most clearly observed in yield spread changes. Thus, the preliminary set of results support the notion that macroeconomic news has perceptible impacts on both corporate bond and Treasury bond yields, but in divergent ways. In addition, there is indication of an asymmetric response to negative versus positive news, and greater sensitivity of speculative bonds compared to investment grade bonds. Therefore, it would be instructive to note that focusing on overall news without recognizing the inherent asymmetry in the yield response to positive and negative news is likely to provide only limited insights into the relationship.

\section{Marginal Impact of News on Bond Yields and Treasury Yields}

In order to more formally examine the marginal and directional impact of macro news on yields, we estimate the following multivariate regression model: 


$$
Y_{B, t}=c+\sum_{i=1}^{19} c_{i} S A_{i, t}+\varepsilon_{t},
$$

where, $Y_{B, t}$ refers to the yield on corporate bond or corresponding yield on the Treasury, and $S A_{i, t}$ represents the standardized surprise of the $i^{t h}$ macroeconomic news announcement. Exhibit 6 reports these regression results.

The results in Exhibit 6 confirm that both corporate and Treasury yields are highly sensitive to macroeconomic news, but react in opposite ways. Examining the response of high yield bonds, we find that 13 out of the 19 macroeconomic news types have a negative and statistically significant impact on high-yield bonds. For instance, a one standard positive (negative) surprise of change in nonfarm payroll causes the average yield of the high yield bonds to decrease (increase) $1.176 \%$ on magnitude. On the other hand, among the coefficients that are significant for the corresponding Treasury yield regression models, only 4 are negative. The remaining 10 are positive. Results from investment bond and corresponding Treasury yield show a similar pattern. The only notable difference is that the magnitudes of the coefficients for the investment bond regression model are in general less than the coefficients in the high-yield bond regression. Interestingly, surprises in CPI have the largest and most pronounced impact on both types of corporate bonds. Summarizing the results, both corporate bond yields and Treasury yields respond to macroeconomic news, and high-yield bonds are more sensitive than investment bond yields. Furthermore, since corporate and Treasury yields respond to macroeconomic news in different way and the magnitudes of the coefficients in the Treasury regressions are generally lower, it would seem that response of yield spreads is more likely to be driven by corporate yields than by corresponding Treasury securities. This is investigated in the next section. 


\section{Marginal Impact of Macroeconomic News on Yield Spreads}

The marginal impact of macroeconomic news on yield spreads is examined by fitting the following pooled regression model:

$$
Y S_{t}=b_{J} \times D J+B_{I} \times D I+\sum_{i=1}^{19} C_{J, i} S A_{i, t} \times D J+\sum_{i=1}^{19} C_{I, i} S A_{I, t} \times D I+\varepsilon_{t},
$$

where $Y S_{t}$ refers to the bond yield-spread at time $t, D J$ and $D I$ are dummy variables for junk and investment bonds, and $S A_{i, t}$ represents the standardized surprises of the $i^{\text {th }}$ macroeconomic news announcement. The coefficients from the regression help us to jointly identify the marginal impact of news on yield spreads for each bond type, and also test for the differential impact on yield spreads. The estimated results are reported in Exhibit 7.

As expected the estimated parameters of the model indicate that high-yield bond spreads are extremely sensitive to news announcements. Notably, news announcements result in a contraction of yield spreads - out of 16 coefficients that are significant, 13 are negative. Coefficients that are positive and significant include Consumer Confidence, Industrial Production, and Personal Income. The results for the investment bonds are similar but marginally weaker pattern as only 9 of the 19 coefficients are found to be statistically significant. All of the statistically coefficients, with the exception of Consumer Confidence, are negative.

It is important to point out that that the intercept terms are positive and highly significant for both high yield and investment bonds. High-yield bonds have an intercept of $8.66 \%$; whereas, investment bonds have an intercept of $1.96 \%$. This corroborates prior evidence that the average yield of the high-yield bond is much higher than of the investment bonds. 
The Wald test of the difference in coefficients confirms that that the magnitude of coefficients on high-yield bonds is significantly higher than investment bonds. For instance, the coefficient for Change in Nonfarm Payroll on high-yield bond spreads is -3.451 versus only 0.756 for investment bond. In other words, a one standard positive (negative) surprise in Nonfarm Payroll causes the average yield spread of high yield bonds to decrease (increase) 3.45\% on magnitude. On the other hand, a one standard deviation positive (negative) shock in the announcement only causes the average yield spread of the investment bonds to decrease (increase) $0.76 \%$ on magnitude. The difference between the impacts of a one standard surprise of change in nonfarm payroll on the average yield spread of high-yield and investment bond is $2.70 \%$ which is statistically significant at the $1 \%$ significance level.

In the next step, we employ a number of control variables to account for bond characteristics that have been commonly associated with yield spread changes. Following previous research (see Bhojraj and Sengupta, 2003; Klock, Mansi and Maxwell, 2005; Oritz-Molina, 2006; and Prevost, Rao and Skousen, 2008), we use three bond-level variables - bond rating index, duration, convexity - plus a quality spread variable that captures macroeconomic effects on bond yields. ${ }^{7}$ We construct the bond rating index using the S\&P bond ratings. Specifically, the bond rating index is four if the rating is $\mathrm{AAA}$ or $\mathrm{AA}$, three if the rating is $\mathrm{A}$ or $\mathrm{BBB}$, two if the rating is $\mathrm{BB}$ or $\mathrm{B}$, and one otherwise. Quality spread is defined as the difference between Baa and Aaa corporate yield indices.

The yield spread regression model with control variables is of the following form:

\footnotetext{
${ }^{7}$ Other controls such as year dummies and weekday dummies were also applied, but are not significant. The results from these regressions are similar to the reported results and are available upon request.
} 


$$
\begin{aligned}
& Y S_{t}=b_{j} D J+c_{J, 1} \text { Rindex }_{t} \times D J+c_{J, 2} \text { Duration }_{t} \times D J+c_{J, 3} \text { Convexity }_{t} \times D J \\
& +c_{J, 4} \text { QualityYie } l d_{t} \times D J+\sum_{i=1}^{19} d_{J, i} S A_{i, t} \times D J \\
& +b_{I} D I+c_{I, 1} \text { Rindex }_{t} \times D I+c_{I, 2} \text { Duration }_{t} \times D I+c_{I, 3} \text { Convexity }_{t} \times D I \\
& +c_{I, 4} \text { QualityYie } l d_{t} \times D J+\sum_{i=1}^{19} d_{I, i} S A_{i, t} \times D I+\varepsilon_{t} .
\end{aligned}
$$

The results of the estimated conditional model are documented in Exhibit 8. The results indicate that when control variables are added into the regression model, the differential response of high-yield and investment bond yield spreads to news becomes even more distinct. Specifically, compared to previous results without controls, we find that economic news variables have a negligible impact on investment grade bond yields spreads; whereas, the impact of news on high-yield bonds is highly pronounced. Notably, the adjusted $\mathrm{R}^{2}$ in the pooled regression model with control variables is about $50 \%$ compared to $18 \%$ for the unconditional model. This dramatic increase shows the importance of the control variables in evaluating yield spread movements.

The coefficients for the four control variables are statistically significant for both models. Note since yield spreads and duration are calculated on an ex post basis, they are expected to be negatively related with each other. Similarly, convexity is expected to be functionally directly related to yield spreads. The documented results support this argument. The positive sign of the quality spread - a countercyclical macroeconomic indicator - indicate that when this spread gets bigger investors require higher yields on corporate high yield bonds than when the quality spread is small.

An examination of Wald test results show that even after including control variables there are 12 announcement coefficients that are significantly different between the high-yield and the 
investment bond responses. For instance, the coefficient of the Change in Nonfarm Payroll is 0.582 on the high-yield bond and only -0.053 on the investment bond. The difference between these two coefficients is 0.530 which is statistically highly significant. Overall, results confirm that: (a) investment bond yield spreads are less sensitive to surprises of macroeconomic announcements; and (b) adding the four important control variables do not meaningfully alter yield spreads responses of speculative grade bonds.

\section{Asymmetric Impact of News on Yield Spreads}

The following regression is estimated to examine the differential response of yield spreads to positive and negative economic news:

$$
Y S_{G, t}=c+\sum_{i=1}^{19} c_{i}^{+} S A_{i, t}^{+}+\sum_{i=1}^{19} c_{i}^{-} S A_{i, t}^{-}+\varepsilon_{G, t}, \text { for } G=I \text { or } J
$$

where $S A_{i, t}^{+}$, and $S A_{i, t}^{-}$refer to the positive and negative standardized surprises of the $i^{t h}$ announcement at time $t$. These results, in Exhibit 9, are reported for high-yield bonds (Panel A) and investment grade bonds (Panel B).

\{Potential Problem: Previously we have shown that control variables are important ... do you think we should examine a version of equation (5) with controls?\} (Hong: We do have one, but we do not report. The results are very similar with and without the control variables.)

An overall evaluation of results in Panels $\mathrm{A}$ and $\mathrm{B}$ indicates that the impact of positive surprises is mixed; in contrast, the response to negative surprises is unambiguous. For high-yield bonds (Panel A), there are about an equal number of positive shocks that result in widening and contracting yield spreads. On the other hand, an overwhelming majority of negative shocks lead 
to an expansion in yield spreads. The responses of investment grade bonds (Panel B) also affirm the importance of negative news.

Furthermore, an analysis of asymmetry shows that there are several announcements where only either positive or negative announcements are significant. Examining Panel A, we notice that for Capital Utilization, Consumer Confidence, CPI, GDP, Personal Income and PPI, only coefficients for the positive surprises are statistically significant. On the other hand, for Advanced Retail Sales, Treasury Budget and Housing Starts, coefficients for only the negative surprises are significant. The Wald test results show that the magnitudes of the coefficients for the positive and negative shocks are statistically different for 12 of the 19 types of macroeconomic announcements.

The signs of the coefficients are also different for different announcements. For example, for both types of bonds, a positive surprise in Nonfarm Payroll is inversely related with yield spreads and a negative surprise in the announcement is positively associated with spreads. In comparison, both positive and negative surprises of Factory Orders increase yield spreads. However, for both these announcements, Wald tests show that yield spreads are more responsive to negative surprises more than positive surprises. For instance, a one standard deviation positive surprise in Nonfarm Payroll causes the average yield spread of high-yield bonds to decrease by approximately $0.61 \%$; whereas, a similar shock to negative surprises widens the average yield spread of high-yield bond by $1.824 \%$.

\section{CONCLUSION}


This study examines the impact of macroeconomic news announcements on the yields and yield spreads of the top fifty most liquid high-yield and investment bonds during the period of 2005 to 2010. Several interesting findings are worth highlighting. First, we find that the two groups of corporate bonds respond to macroeconomic news announcements differently. Highyield bonds are more sensitive to macroeconomic news than investment grade bonds. Second, the responds of yields of corporate bonds respond to macroeconomic news are opposite to the Treasury bonds. Specifically, better (worse) than expected news leads to decrease (increase) of yields on corporate bonds and increase (decrease) of yields on Treasury bonds. In other words, when news about the economy is better than expected, investors tend to fly to high risk and high return corporate bonds; whereas worse than expected economic indicators attract investors to safer Treasury bonds. Third, similar to equity markets, corporate bonds are found to be relatively more sensitive to negative economic shocks than positive shocks. Finally, the use of bond-level control variables accentuates the yield spread response of speculative grade bonds to news. 


\section{References}

Prevost, A.K., R.P. Rao, and C.J. Skousen. 2008. Earnings management and the cost of debt. Available at SSRN: http://ssrn.com/abstract=1083808.

Bhojraj, S. and P. Sengupta. 2003. Effect of corporate governance and bond ratings and yields: The role of institutional investors and outside directors. Journal of Business 76, 455-475.

Klock, M., S. Mansi and W. Maxwell. 2005. Does corporate governance matter to bondholders? Journal of Financial and Quantitative Analysis 40, 693-719.

Ortiz-Molina, H. 2006. Top management incentives and the pricing of corporate public debt. Journal of Financial and Quantitative Analysis 41, 317-340.

Taylor, Stephen J. "Stock Index And Price Dynamics in The UK And The US: New Evidence From A Trading Rule and Statistical Analysis." European Journal of Finance 6 (2000), pp. 3969. 


\section{EXHIBIT 1}

Summary of Bond Transactions Reported in TRACE

Panel A: All Bonds in TRACE

\begin{tabular}{lrrrcrc}
\hline Year & $\begin{array}{c}\text { Number } \\
\text { of Bonds }\end{array}$ & $\begin{array}{c}\text { Number of } \\
\text { Transactions }\end{array}$ & $\begin{array}{c}\text { Total Number of Days } \\
\text { with Transactions }\end{array}$ & $\begin{array}{c}\text { Average Number } \\
\text { of Transactions } \\
\text { Per Bond }\end{array}$ & $\begin{array}{c}\text { Average Number of } \\
\text { Transactions Per Bond } \\
\text { Per day }\end{array}$ & $\begin{array}{c}\text { Average Number } \\
\text { of Days with } \\
\text { Transactions }\end{array}$ \\
\hline 2005 & 23,528 & $6,239,606$ & $1,181,764$ & 265.2 & 1.05 & 50.2 \\
2006 & 22,726 & $5,540,040$ & $1,183,512$ & 243.8 & 0.97 & 52.1 \\
2007 & 23,689 & $5,073,359$ & $1,093,723$ & 214.2 & 1.85 & 46.2 \\
2008 & 23,542 & $6,702,337$ & $1,038,568$ & 284.7 & 1.83 & 54.1 \\
2009 & 24,750 & $11,401,270$ & $1,297,493$ & 460.7 & 1.37 & 46.4 \\
2010 & 32,116 & $11,088,216$ & $1,490,002$ & 345.3 & & \\
\hline
\end{tabular}

Panel B: Top Fifty High-yield and Investment Bonds

\begin{tabular}{|c|c|c|c|c|c|c|c|}
\hline Year & $\begin{array}{l}\text { Bond } \\
\text { Rating } \\
\text { Grade }\end{array}$ & $\begin{array}{l}\text { Number } \\
\text { of Bonds }\end{array}$ & $\begin{array}{l}\text { Number of } \\
\text { Transactions }\end{array}$ & $\begin{array}{c}\text { Total Number of Days } \\
\text { with Transactions }\end{array}$ & $\begin{array}{c}\text { Average Number } \\
\text { of Transactions } \\
\text { Per Bond }\end{array}$ & $\begin{array}{c}\text { Average Number of } \\
\text { Transactions Per Bond } \\
\text { Per day }\end{array}$ & $\begin{array}{c}\text { Average Number } \\
\text { of Days with } \\
\text { Transactions }\end{array}$ \\
\hline \multirow{2}{*}{2005} & Investment & 50 & 348,551 & 12,443 & $6,971.0$ & 27.7 & 248.9 \\
\hline & Speculative & 50 & 734,479 & 11,605 & $14,689.6$ & 58.3 & 232.1 \\
\hline \multirow{2}{*}{2006} & Investment & 50 & 355,190 & 12,335 & $7,103.8$ & 28.2 & 246.7 \\
\hline & Speculative & 50 & 371,589 & 12,341 & $7,431.8$ & 29.5 & 246.8 \\
\hline \multirow{2}{*}{2007} & Investment & 50 & 317,164 & 11,251 & $6,343.3$ & 25.2 & 225.0 \\
\hline & Speculative & 50 & 281,995 & 12,419 & $5,639.9$ & 22.4 & 248.4 \\
\hline \multirow{2}{*}{2008} & Investment & 50 & 685,061 & 11,968 & $13,701.2$ & 54.4 & 239.4 \\
\hline & Speculative & 50 & 345,361 & 12,206 & $6,907.2$ & 27.4 & 244.1 \\
\hline \multirow{2}{*}{2009} & Investment & 50 & $1,066,635$ & 12,509 & $21,332.7$ & 84.7 & 250.2 \\
\hline & Speculative & 50 & 312,294 & 10,739 & $6,245.9$ & 24.8 & 214.8 \\
\hline \multirow{2}{*}{2010} & Investment & 50 & 793,250 & 11,954 & $15,865.0$ & 63.0 & 239.1 \\
\hline & Speculative & 50 & 533,099 & 11,968 & $10,662.0$ & 42.3 & 239.4 \\
\hline
\end{tabular}




\section{EXHIBIT 2}

\section{Descriptive Statistics of Sample Bonds}

Panel A: Raw Data

\begin{tabular}{|c|c|c|c|c|c|c|c|c|c|c|c|c|}
\hline Variable & $\mathbf{I} / \mathrm{S}^{*}$ & Obs & Mean & Min & Max & Median & $1 \%$ & $5 \%$ & $10 \%$ & $90 \%$ & $95 \%$ & $99 \%$ \\
\hline \multirow{2}{*}{ Yield } & $\mathrm{I}$ & 72280 & 5.28 & 0.00 & 171.70 & 5.21 & 0.00 & 2.51 & 3.55 & 6.81 & 7.90 & 11.59 \\
\hline & $\mathrm{S}$ & 70884 & 23.91 & 0.00 & 159406.99 & 8.88 & 0.00 & 0.00 & 4.63 & 21.44 & 33.79 & 130.31 \\
\hline \multirow{2}{*}{ Yield Spread } & I & 72280 & 1.90 & -4.74 & 167.83 & 1.29 & -0.54 & 0.30 & 0.39 & 4.13 & 5.48 & 9.61 \\
\hline & $\mathrm{S}$ & 70884 & 20.78 & -5.42 & 159403.73 & 5.23 & -4.42 & -1.15 & 1.65 & 19.27 & 31.50 & 130.15 \\
\hline \multirow{2}{*}{ Price } & I & 72280 & 99.96 & 39.85 & 343.59 & 100.16 & 77.43 & 89.00 & 93.78 & 107.04 & 108.70 & 112.94 \\
\hline & $\mathrm{S}$ & 70884 & 86.15 & 0.00 & 230.16 & 93.35 & 12.11 & 40.96 & 60.24 & 102.00 & 104.57 & 109.72 \\
\hline \multirow{2}{*}{$\begin{array}{l}\text { Volume } \\
\text { (in } \$ 1000 \text { ) }\end{array}$} & I & 72280 & 10,128 & 1 & 518,786 & 4,361 & 64 & 260 & 499 & 25,506 & 38,371 & 78,122 \\
\hline & $\mathrm{S}$ & 70884 & 7,928 & 1 & 932,078 & 3,126 & 20 & 120 & 267 & 18,021 & 28,866 & 73,798 \\
\hline \multirow{2}{*}{$\mathrm{TTM}(\mathrm{y})$} & I & 72280 & 6.02 & NA & 57.86 & 5.04 & 0.07 & 0.70 & 1.23 & 9.62 & 24.78 & 29.71 \\
\hline & $\mathrm{S}$ & 70884 & 6.13 & NA & 40.12 & 4.08 & 0.12 & 0.57 & 0.96 & 16.41 & 23.27 & 26.71 \\
\hline \multirow{2}{*}{ Duration } & I & 72280 & 4.62 & 0.01 & 15.45 & 4.33 & 0.27 & 0.76 & 1.25 & 7.24 & 11.46 & 13.23 \\
\hline & $\mathrm{S}$ & 70884 & 3.76 & 0.00 & 16.00 & 3.29 & 0.13 & 0.54 & 0.90 & 7.61 & 8.98 & 10.71 \\
\hline \multirow{2}{*}{ Convexity } & I & 72280 & 39.35 & 0.01 & 338.41 & 22.54 & 0.20 & 0.95 & 2.19 & 64.87 & 196.92 & 274.56 \\
\hline & $\mathrm{S}$ & 70884 & 29.96 & 0.00 & 326.86 & 13.63 & 0.07 & 0.56 & 1.25 & 90.62 & 137.85 & 186.29 \\
\hline
\end{tabular}

Notes: * I/S refer to whether the bond is investment or speculative grade. 
Panel B: Cleaned Data

\begin{tabular}{|c|c|c|c|c|c|c|c|c|c|c|c|c|}
\hline Variable & $\mathbf{I} / \mathbf{S}^{*}$ & Obs & Mean & Min & Max & Median & $1 \%$ & $5 \%$ & $10 \%$ & $90 \%$ & $95 \%$ & $99 \%$ \\
\hline \multirow{2}{*}{ Yield } & I & 70951 & 5.37 & 0.001 & 74.98 & 5.23 & 1.42 & 2.99 & 3.76 & 6.83 & 7.94 & 11.63 \\
\hline & $\mathrm{S}$ & 65899 & 11.89 & 0.002 & 99.98 & 9.09 & 1.67 & 4.80 & 6.00 & 20.48 & 30.59 & 59.38 \\
\hline \multirow{2}{*}{ Yield Spread } & I & 70951 & 1.93 & -4.03 & 73.49 & 1.30 & 0.18 & 0.32 & 0.40 & 4.15 & 5.50 & 9.64 \\
\hline & $\mathrm{S}$ & 65899 & 8.57 & -5.29 & 99.77 & 5.38 & -2.64 & 1.65 & 2.30 & 18.18 & 28.14 & 56.65 \\
\hline \multirow{2}{*}{ Price } & I & 70951 & 100.13 & 39.85 & 343.59 & 100.22 & 77.94 & 90.37 & 94.18 & 107.10 & 108.74 & 113.00 \\
\hline & $\mathrm{S}$ & 65899 & 87.91 & 0.11 & 230.16 & 93.72 & 25.68 & 51.28 & 65.35 & 102.02 & 104.52 & 109.51 \\
\hline \multirow{2}{*}{$\begin{array}{l}\text { Volume } \\
\text { (in 1000) }\end{array}$} & I & 70951 & 9,932 & 1 & 518,786 & 4,306 & 63 & 258 & 494 & 25,058 & 38,627 & 75,365 \\
\hline & $\mathrm{S}$ & 65899 & 8,049 & 1 & 932,078 & 3,191 & 22 & 127 & 280 & 18,234 & 29,301 & 75,440 \\
\hline \multirow{2}{*}{ TTM(y) } & I & 70951 & 6.38 & 0.01 & 30.06 & 5.09 & 0.28 & 0.79 & 1.31 & 9.58 & 23.11 & 29.60 \\
\hline & $\mathrm{S}$ & 65899 & 6.33 & 0.01 & 40.12 & 4.17 & 0.24 & 0.67 & 1.07 & 16.13 & 23.27 & 26.89 \\
\hline \multirow{2}{*}{ Duration } & I & 70951 & 4.62 & 0.01 & 15.45 & 4.33 & 0.27 & 0.76 & 1.25 & 7.24 & 11.46 & 13.23 \\
\hline & $\mathrm{S}$ & 65899 & 3.81 & 0.01 & 16.00 & 3.33 & 0.23 & 0.62 & 0.96 & 7.64 & 8.99 & 10.72 \\
\hline \multirow{2}{*}{ Convexity } & I & 70951 & 39.36 & 0.01 & 338.41 & 22.54 & 0.20 & 0.95 & 2.19 & 64.87 & 196.92 & 274.56 \\
\hline & $\mathrm{S}$ & 65899 & 30.36 & 0.00 & 326.86 & 13.94 & 0.16 & 0.68 & 1.40 & 91.46 & 138.35 & 186.44 \\
\hline
\end{tabular}

Notes: * I/S refer to whether the bond is investment or speculative grade. 


\section{EXHIBIT 3}

\section{Summary Statistics of U.S. Macroeconomic News}

\begin{tabular}{|c|c|c|c|c|}
\hline Time & News & Obs. & Mean & Std. Dev. \\
\hline \multirow{10}{*}{$8: 30$} & Advanced Retail Sales (ARS) & 72 & 0.0001 & 0.0060 \\
\hline & Change in Nonfarm Payroll (CNP) & 72 & -13.6667 & 66.6115 \\
\hline & Consumer Confidence (CC) & 72 & -0.1417 & 4.9822 \\
\hline & Consumer Price Index (CPI) & 72 & 0.0000 & 0.0015 \\
\hline & Gross Domestic Product (GDP) & 72 & -0.0004 & 0.0046 \\
\hline & Housing Starts (HS) & 72 & 1.4167 & 88.0807 \\
\hline & Personal Income (PI) & 72 & 0.0007 & 0.0035 \\
\hline & Producer Price Index (PPI) & 72 & 0.0005 & 0.0056 \\
\hline & Trade Balance Goods and Services (TBGS) & 72 & 0.3125 & 3.5466 \\
\hline & Unemployment Rate (UR) & 72 & 0.0000 & 0.0015 \\
\hline \multirow{2}{*}{$9: 15$} & Capacity Utilization (CU) & 72 & -0.0005 & 0.0037 \\
\hline & Industrial Production (IP) & 72 & -0.0006 & 0.0044 \\
\hline \multirow{5}{*}{ 10:00 } & Business Inventories (BI) & 72 & -0.0001 & 0.0023 \\
\hline & Construction Spending (CS) & 72 & 0.0013 & 0.0077 \\
\hline & Factory Orders (FO) & 72 & 0.0001 & 0.0076 \\
\hline & National Association of Purchasing Management (NAPM) & 72 & 0.2708 & 2.1053 \\
\hline & New Home Sales (NHS) & 72 & -1.2361 & 68.2882 \\
\hline $14: 00$ & Treasury Budget Statement (BST) & 72 & -0.2403 & 11.0579 \\
\hline $14: 15$ & Federal Open Market Committee (FOMC) & 50 & -0.0001 & 0.0005 \\
\hline
\end{tabular}




\section{EXHIBIT 4}

\section{Summary Statistics}

\section{Panel A: News Vs. No-news (All)}

\begin{tabular}{|c|c|c|c|c|c|c|c|c|c|c|c|c|c|c|c|c|c|c|c|}
\hline \multirow{2}{*}{$\begin{array}{l}\text { News } \\
\text { No. }\end{array}$} & \multirow[t]{2}{*}{ Days } & \multicolumn{3}{|c|}{ High-Yield Bond } & \multicolumn{3}{|c|}{ Treasury Yield } & \multicolumn{3}{|c|}{ High-Yield Spread } & \multicolumn{3}{|c|}{ Investment Bond } & \multicolumn{3}{|c|}{ Treasury Yield } & \multicolumn{3}{|c|}{$\begin{array}{c}\text { Investment Yield } \\
\text { Spread }\end{array}$} \\
\hline & & ield & iff. & Z-stat & Yield & iff. & Z-stat & YS & Diff. & Z-stat & Yield & Diff. & Z-stat & Yield & Diff & Z-stat & YS & Diff. & Z-stat \\
\hline \multicolumn{20}{|c|}{ Number of news } \\
\hline 1 & 428 & .059 & $0.322^{\mathrm{a}}$ & 3.463 & 3.357 & $0.022^{\mathrm{c}}$ & 1.561 & 8.703 & $0.300^{\mathrm{a}}$ & 3.103 & 5.461 & $0.141^{\mathrm{a}}$ & & 3.472 & $0.035^{\mathrm{a}}$ & 26 & 1.989 & $0.106^{\mathrm{a}}$ & 4.673 \\
\hline 2 & 37 & 2.098 & $0.361^{\mathrm{a}}$ & 3.130 & 3.269 & $-0.065^{\mathrm{a}}$ & -3.768 & 8.829 & $0.427^{\mathrm{a}}$ & 3.569 & 5.360 & $0.040^{\mathrm{b}}$ & 1.698 & 3.388 & $-0.048^{\mathrm{a}}$ & -3.359 & 1.972 & $0.088^{\mathrm{a}}$ & 3.364 \\
\hline 3 & 72 & 12.203 & $0.466^{\mathrm{b}}$ & 2.285 & 3.158 & $-0.177^{\mathrm{a}}$ & -5.776 & 9.045 & $0.643^{\mathrm{a}}$ & 3.035 & 5.316 & -0.004 & -0.097 & 3.284 & $-0.153^{\mathrm{a}}$ & -6.031 & 2.033 & $0.149^{\mathrm{a}}$ & 3.597 \\
\hline 4 & 14 & 10.323 & $-1.414^{\mathrm{a}}$ & -5.941 & 3.436 & $0.102^{\mathrm{b}}$ & 2.051 & 6.887 & $-1.515^{\mathrm{a}}$ & -6.227 & 4.953 & $-0.367^{\mathrm{a}}$ & -7.830 & 3.513 & $0.077^{\mathrm{b}}$ & 1.885 & 1.440 & $-0.444^{\mathrm{a}}$ & -8.739 \\
\hline 6 & 1 & 1.060 & -0.677 & -0.772 & 4.364 & $1.030^{\mathrm{a}}$ & 32.327 & 6.696 & $-1.706^{b}$ & -1.948 & 4.822 & $-0.498^{\mathrm{a}}$ & -9.034 & 4.305 & $0.869^{\mathrm{a}}$ & 43.423 & 0.517 & $-1.367^{\mathrm{a}}$ & -29.455 \\
\hline & 760 & .737 & & & 3.335 & & & 8.402 & & & 5.320 & & & 3.437 & & & 1.883 & & \\
\hline \multicolumn{20}{|c|}{ Positive, Negative and Mixed } \\
\hline \multicolumn{20}{|l|}{ (Sign) } \\
\hline Negative & 295 & .412 & $0.675^{\mathrm{a}}$ & 6.003 & 3.309 & $-0.026^{c}$ & -1.604 & 9.103 & $0.701^{\mathrm{a}}$ & 6.002 & 5.474 & $54^{\mathrm{a}}$ & 6.399 & 3.416 & $-0.020^{c}$ & -1.544 & 2.058 & $0.174^{\mathrm{a}}$ & 6.455 \\
\hline & 286 & 11.657 & -0.080 & -0.808 & 3.353 & 0.018 & 1.092 & 8.304 & -0.098 & -0.949 & 5.366 & $0.046^{\mathrm{b}}$ & 2.206 & 3.481 & $0.045^{\mathrm{a}}$ & 3.300 & 1.884 & 0.001 & 0.042 \\
\hline Mixed & 171 & 12.092 & $0.355^{\mathrm{a}}$ & 2.682 & 3.255 & $-0.080^{\mathrm{a}}$ & -4.014 & 8.837 & $0.435^{\mathrm{a}}$ & 3.169 & 5.351 & 0.030 & 1.133 & 3.366 & $-0.070^{\mathrm{a}}$ & -4.262 & 1.984 & $0.101^{\mathrm{a}}$ & 3.332 \\
\hline
\end{tabular}


Panel B: Disaggregated by News Type

\begin{tabular}{|c|c|c|c|c|c|c|c|c|c|c|c|c|c|c|c|c|c|c|}
\hline \multirow[t]{2}{*}{ News } & \multicolumn{3}{|c|}{ High-Yield Bond } & \multicolumn{3}{|c|}{ Treasury Yield } & \multicolumn{3}{|c|}{ High-Yield Spread } & \multicolumn{3}{|c|}{ Investment Bond } & \multicolumn{3}{|c|}{ Treasury Yield } & \multicolumn{3}{|c|}{$\begin{array}{c}\text { Investment Yield } \\
\text { Spread }\end{array}$} \\
\hline & ield & Diff. & Z-stat & Yield & Diff. & Z-stat & $\mathbf{Y S}$ & Diff. & Z-stat & Yield & Diff. & Z-stat & Yield & Diff. & Z-stat & YS & Diff. & Z-stat \\
\hline$\overline{\mathrm{ARS}}$ & 2.023 & $0.286^{\mathrm{c}}$ & 1.406 & 3.329 & -0.006 & -0.202 & 8.695 & $0.293^{\mathrm{c}}$ & 1.384 & 5.335 & 0.015 & 0.393 & 3.426 & -0.011 & -0.445 & 1.910 & 0.026 & 0.601 \\
\hline BI & .650 & $0.913^{\mathrm{a}}$ & 4.048 & 162 & $-0.173^{\mathrm{a}}$ & -5.287 & 9.488 & $1.086^{\mathrm{a}}$ & 4.651 & 5.389 & $0.068^{\mathrm{c}}$ & 1.581 & 3.307 & $-0.130^{a}$ & 21 & 2.082 & $0.199^{\mathrm{a}}$ & 4.110 \\
\hline BST & .775 & 0.038 & 0.203 & 3.368 & 0.033 & 1.158 & 8.407 & 0.005 & 0.026 & 5.316 & -0.004 & -0.109 & 3.476 & $0.039^{\mathrm{c}}$ & 39 & 1.841 & -0 . & -1.090 \\
\hline $\mathrm{CC}$ & 786 & & 0.260 & 345 & & & 8.441 & & & 5.367 & & & & & & & & 0.908 \\
\hline $\mathrm{CNP}$ & .925 & 0.188 & 1.008 & 309 & -0.026 & -0.8 & 8.616 & 0.214 & 05 & 5.342 & 22 & 0.599 & 3.429 & -0.008 & -0.319 & 1.913 & 0.030 & 0.711 \\
\hline CPI & .293 & $0.556^{\mathrm{a}}$ & & 5 & & & 8.938 & $0.536^{\mathrm{b}}$ & & 5.355 & & & & & & & & 0.676 \\
\hline $\mathrm{CS}$ & .820 & 0.083 & 0.454 & 3.293 & $-0.042^{c}$ & -1.457 & 8.527 & 0.125 & 0.657 & 5.397 & $0.077^{\mathrm{b}}$ & 1.673 & 3.414 & -0.023 & -0.936 & 1.983 & $0.100^{b}$ & 1.968 \\
\hline $\mathrm{CU}$ & .210 & $0.473^{\mathrm{b}}$ & 2.314 & 3.308 & -0.026 & -0.889 & 8.901 & $0.499^{\mathrm{a}}$ & 2.354 & 5.383 & $0.062^{\mathrm{c}}$ & 1.595 & 3.415 & -0.022 & 88 & 1.968 & $0.084^{b}$ & 1.903 \\
\hline FO & .785 & 0.048 & 0.256 & 3.310 & -0.025 & -0.869 & 8.475 & $0 .($ & 0.377 & 5.365 & 0. & 1.225 & 3.426 & -0 & 54 & 1.939 & & 1.332 \\
\hline FOM & .488 & $10.751^{\mathrm{a}}$ & 6.402 & 2.542 & $-0.793^{a}$ & -5.528 & 19.947 & $11.545^{\mathrm{a}}$ & 6.587 & 6.397 & $1.077^{\mathrm{a}}$ & 8.153 & 2.660 & $-0.776^{\mathrm{a}}$ & -6 . & 3.736 & $1.853^{\mathrm{a}}$ & 10.312 \\
\hline GDP & .597 & -0.140 & -0.718 & 3.296 & -0.039 & -1.209 & 8.301 & -0.102 & -0.501 & 5.309 & -0 . & -0.263 & 3.435 & -0.002 & 76 & 1.874 & -0 & -0.194 \\
\hline HS & .011 & $0.274^{\mathrm{c}}$ & 1.453 & 3.360 & 0.025 & 0.890 & 8.650 & 0.248 & 1.268 & 5.486 & $0.166^{\mathrm{a}}$ & 3.498 & 3.460 & 0.024 & 00 & 2.026 & $0.142^{\mathrm{a}}$ & 2.699 \\
\hline IP & .267 & & 2.512 & 3.274 & $-0.061^{b}$ & -1.992 & 8.993 & $0.591^{\mathrm{a}}$ & 2.696 & 5.384 & $0.063^{\mathrm{c}}$ & 1.566 & 3.385 & $-0.051^{b}$ & 39 & 1.998 & & 2.492 \\
\hline NAPM & .771 & 0.034 & 0.191 & 3.284 & $-0.051^{b}$ & -1.770 & 8.488 & 0.085 & 0.455 & 5.359 & 0.038 & 0.856 & 3.407 & -0.030 & 41 & 1.952 & $0.068^{\mathrm{c}}$ & 1.375 \\
\hline NHS & .972 & & 1.222 & 3.324 & & -0.387 & 8.649 & 0.247 & 1.235 & 5.370 & 0.0 & 1.290 & 3.435 & -0.001 & & 1.935 & & 1.181 \\
\hline PI & .395 & $0.658^{\mathrm{a}}$ & 3.039 & 3.180 & $-0.155^{\mathrm{a}}$ & -4.962 & 9.215 & $0.813^{\mathrm{a}}$ & 3.623 & 5.381 & $0.061^{\mathrm{c}}$ & 1.558 & 3.316 & $-0.120^{a}$ & -4.678 & 2.065 & $0.181^{\mathrm{a}}$ & 4.100 \\
\hline PPI & .736 & -0.001 & -0.003 & 3.344 & 0.009 & 0.309 & 8.393 & -0.010 & -0.051 & 5.332 & 0.012 & 0.366 & 3.455 & 0.018 & & 1.877 & -0.006 & -0.166 \\
\hline TBGS & 1.915 & 0.178 & 0.927 & 3.312 & -0.023 & -0.785 & 8.603 & 0.201 & 1.006 & 5.370 & 0.050 & 1.249 & 3.423 & -0.014 & -0 . & 1.947 & & 1.422 \\
\hline UR & 12.027 & $0.290^{c}$ & 1.336 & 3.117 & $-0.218^{\mathrm{a}}$ & -6.431 & 8.910 & $0.508^{\mathrm{b}}$ & 2.261 & 5.266 & $-0.054^{\mathrm{c}}$ & -1.354 & 3.272 & $-0.165^{\mathrm{a}}$ & -5.887 & 1.995 & $0.111^{\mathrm{a}}$ & 2.453 \\
\hline No-News & 11.737 & & & 3.335 & & & 8.402 & & & 5.320 & & & 3.437 & & & 1.883 & & \\
\hline
\end{tabular}




\section{EXHIBIT 5}

\section{Bond Yields on Days with Positive and Negative Surprises}

\section{Panel A: Positive Surprise}

\begin{tabular}{|c|c|c|c|c|c|c|c|c|c|c|c|c|c|c|c|c|c|c|}
\hline \multirow[t]{2}{*}{ News } & \multicolumn{3}{|c|}{ High-Yield Bond } & \multicolumn{3}{|c|}{ Treasury Yield } & \multicolumn{3}{|c|}{ High-Yield Spread } & \multicolumn{3}{|c|}{ Investment Bond } & \multicolumn{3}{|c|}{ Treasury Yield } & \multicolumn{3}{|c|}{$\begin{array}{c}\text { Investment Yield } \\
\text { Spread }\end{array}$} \\
\hline & Yield & Diff. & Z-stat & Yield & Diff. & Z-stat & YS & Diff & Z-stat & Yield & Diff. & Z-stat & Yield & Diff. & Z-stat & YS & Diff. & Z-stat \\
\hline$\overline{\mathrm{ARS}}$ & 11.414 & -0.323 & -1.170 & 3.189 & $-0.146^{\mathrm{a}}$ & -3.507 & 8.226 & -0.177 & -0.621 & 5.160 & $-0.160^{\mathrm{a}}$ & -3.538 & 3.310 & $-0.127^{\mathrm{a}}$ & -3.741 & 1.850 & -0.034 & -0.686 \\
\hline BI & 10.600 & $-1.137^{\mathrm{a}}$ & -5.197 & 3.427 & $0.092^{\mathrm{b}}$ & 961 & 7.173 & $-1.229^{a}$ & -5.528 & 5.075 & $-0.245^{\mathrm{a}}$ & -6.445 & 3.542 & $0.105^{\mathrm{a}}$ & 2.641 & 1.534 & $-0.350^{\mathrm{a}}$ & -9.567 \\
\hline BST & 1.954 & 0.217 & 0.736 & 3.504 & $0.169^{\mathrm{a}}$ & 3.930 & 8.451 & 0.048 & 0.158 & 5.518 & $0.198^{\mathrm{a}}$ & 3.274 & 3.582 & $0.145^{\mathrm{a}}$ & 3.957 & 1.936 & 0.053 & 0.768 \\
\hline $\mathrm{CC}$ & 1.573 & -0.163 & -0.670 & 3.504 & $0.169^{\mathrm{a}}$ & 4.531 & 8.069 & $-0.333^{c}$ & -1.322 & 5.369 & 0.049 & 0.797 & 3.583 & $0.147^{\mathrm{a}}$ & 4.667 & 1.786 & $-0.097^{\mathrm{c}}$ & -1.466 \\
\hline CNP & .854 & $-0.883^{\mathrm{a}}$ & -3.895 & 3.363 & 0.028 & 0.653 & 7.491 & $-0.912^{a}$ & -3.914 & 5.153 & $-0.168^{a}$ & -4.282 & 3.503 & 0.0 & 1. & 1.649 & $-0.234^{\mathrm{a}}$ & -5.511 \\
\hline CPI & .637 & -0.100 & -0.396 & 3.575 & $0.240^{\mathrm{a}}$ & 5.749 & 8.062 & $-0.340^{c}$ & -1.282 & 5.344 & 0.024 & 0.512 & 3.635 & $0.198^{\mathrm{a}}$ & 5.547 & 1.709 & $-0.175^{\mathrm{a}}$ & -3.162 \\
\hline $\mathrm{CS}$ & & -0.0 & -0.022 & 3.139 & $-0.196^{\mathrm{a}}$ & -4.719 & 8.593 & 0.191 & 0.749 & 5.435 & $0.115^{\mathrm{c}}$ & 1.533 & 3.277 & $-0.160^{\mathrm{a}}$ & -4.658 & 2.158 & $0.274^{\mathrm{a}}$ & 3.429 \\
\hline $\mathrm{CU}$ & .655 & $-1.082^{a}$ & -4.864 & 3.371 & 0.036 & 0.875 & 7.284 & $-1.118^{\mathrm{a}}$ & -4.893 & 5.077 & $-0.243^{\mathrm{a}}$ & -6.857 & 3.513 & $0.077^{\mathrm{b}}$ & 2.285 & 1.564 & $-0.319^{a}$ & -8.833 \\
\hline FO & .213 & $-0.524^{a}$ & -2.473 & 3.418 & $0.084^{\mathrm{b}}$ & 2.237 & 7.795 & $-0.607^{a}$ & -2.752 & 5.270 & -0.050 & -1.186 & 3.548 & $0.112^{\mathrm{a}}$ & 3. & 1.722 & $-0.161^{\mathrm{a}}$ & -3.500 \\
\hline FOMC & 21.286 & $9.549^{\mathrm{a}}$ & 4.764 & 1.370 & $-1.965^{\mathrm{a}}$ & -14.595 & 19.916 & $11.514^{\mathrm{a}}$ & 5.596 & 6.603 & $1.283^{\mathrm{a}}$ & 4.542 & 2.135 & $-1.301^{\mathrm{a}}$ & -10.320 & 4.467 & $2.584^{\mathrm{a}}$ & 9.960 \\
\hline GDP & .153 & $0.416^{\mathrm{c}}$ & 1.334 & 2.855 & $-0.479^{a}$ & -9.554 & 9.297 & $0.895^{\mathrm{a}}$ & 2.783 & 5.238 & $-0.082^{c}$ & -1.417 & 3.080 & $-0.356^{\mathrm{a}}$ & -8 & 2.158 & $0.274^{\mathrm{a}}$ & 4.363 \\
\hline $\mathrm{HS}$ & 11.266 & $-0.471^{b}$ & -2.020 & 3.499 & $0.164^{\mathrm{a}}$ & 4.433 & 7.767 & $-0.635^{a}$ & -2.631 & 5.305 & -0 & -0.306 & 3.582 & $0.146^{\mathrm{a}}$ & 4.718 & 1.723 & $-0.161^{\mathrm{a}}$ & -3.013 \\
\hline IP & 1.975 & 0.238 & 0.769 & 3.037 & $-0.298^{\mathrm{a}}$ & -6.884 & 8.938 & $0.536^{\mathrm{b}}$ & 1.688 & 5.170 & $-0.150^{\mathrm{a}}$ & -3.299 & 3.185 & $-0.251^{\mathrm{a}}$ & -7.087 & 1.985 & $0.101^{\mathrm{b}}$ & 2.037 \\
\hline NAPM & 1.343 & $-0.394^{b}$ & -1.895 & 3.048 & $-0.287^{a}$ & -7.494 & 8.295 & -0.107 & -0.494 & 5.218 & $-0.103^{\mathrm{a}}$ & -2.547 & 3.234 & $-0.202^{\mathrm{a}}$ & -6.367 & 1.983 & $0.100^{\mathrm{b}}$ & 2.165 \\
\hline NHS & 1.693 & -0.043 & -0.164 & 3.492 & $0.157^{\mathrm{a}}$ & 3.478 & 8.202 & -0.200 & -0.722 & 5.425 & $0.105^{\mathrm{b}}$ & 1.698 & 3.599 & $0.163^{\mathrm{a}}$ & 4.373 & 1.826 & -0.058 & -0.830 \\
\hline PI & .736 & -0.001 & -0.003 & 3.344 & 0.009 & 0.309 & 8.393 & -0.010 & -0.051 & 5.332 & 0.012 & 0.366 & 3.455 & 0.0 & 0 . & 1.877 & -0.006 & -0.166 \\
\hline PPI & .014 & $-0.723^{a}$ & -3.753 & 3.425 & $0.091^{\mathrm{a}}$ & 2.392 & 7.589 & $-0.813^{a}$ & -4.058 & 5.263 & $-0.058^{\mathrm{c}}$ & -1.529 & 3.544 & $0.107^{\mathrm{a}}$ & & 1.719 & $-0.165^{\mathrm{a}}$ & -3.825 \\
\hline TBGS & 1.681 & -0.056 & -0.248 & 3.315 & -0.020 & -0.516 & 8.366 & -0.036 & -0.153 & 5.331 & 0.011 & 0.277 & 3.430 & -0.007 & -0.223 & 1.902 & 0.018 & 0.387 \\
\hline UR & 10.814 & $-0.923^{a}$ & -3.471 & 3.269 & $-0.066^{c}$ & -1.486 & 7.545 & $-0.857^{\mathrm{a}}$ & -3.146 & 4.994 & $-0.327^{\mathrm{a}}$ & -7.409 & 3.380 & $-0.057^{\mathrm{c}}$ & -1.547 & 1.614 & $-0.270^{\mathrm{a}}$ & -5.455 \\
\hline No-News & 11.737 & & & 3.335 & & & 8.402 & & & 5.320 & & & 3.437 & & & 1.883 & & \\
\hline
\end{tabular}




\section{Panel B: Negative Surprises}

\begin{tabular}{|c|c|c|c|c|c|c|c|c|c|c|c|c|c|c|c|c|c|c|}
\hline \multirow[t]{2}{*}{ News } & \multicolumn{3}{|c|}{ High-Yield Bond } & \multicolumn{3}{|c|}{ Treasury Yield } & \multicolumn{3}{|c|}{ High-Yield Spread } & \multicolumn{3}{|c|}{ Investment Bond } & \multicolumn{3}{|c|}{ Treasury Yield } & \multicolumn{3}{|c|}{$\begin{array}{c}\text { Investment Yield } \\
\text { Spread } \\
\end{array}$} \\
\hline & ield & Diff. & Z-stat & Yield & Diff. & Z-stat & YS & Diff & Z-stat & Yield & Diff. & Z-stat & Yield & Diff. & Z-stat & YS & Diff. & Z-stat \\
\hline$\overline{\mathrm{ARS}}$ & 12.694 & $0.957^{\mathrm{a}}$ & 3.311 & 3.483 & $0.148^{\mathrm{a}}$ & 3.683 & 9.211 & $0.809^{\mathrm{a}}$ & 2.676 & 5.542 & $0.222^{\mathrm{a}}$ & 3.528 & 3.562 & $0.125^{\mathrm{a}}$ & 3.662 & 1.980 & $0.097^{\mathrm{c}}$ & 1.319 \\
\hline BI & .505 & $2.769^{\mathrm{a}}$ & 7.552 & 2.922 & $-0.413^{\mathrm{a}}$ & -9.558 & 11.583 & $3.181^{\mathrm{a}}$ & 8.371 & 5.658 & $0.338^{\mathrm{a}}$ & 4.735 & 3.104 & $-0.332^{\mathrm{a}}$ & -9.620 & 2.554 & $0.670^{\mathrm{a}}$ & 8.328 \\
\hline BST & .627 & -0.110 & -0.472 & 3.255 & $-0.080^{\mathrm{b}}$ & -2.177 & 8.371 & -0.031 & -0.127 & 5.154 & $-0.166^{\mathrm{a}}$ & -4.469 & 3.390 & $-0.046^{\mathrm{c}}$ & -1 . & 1.764 & $-0.120^{\mathrm{a}}$ & -2.873 \\
\hline $\mathrm{CC}$ & .027 & 0.290 & 1.045 & 3.164 & $-0.171^{\mathrm{a}}$ & -4.195 & 8.862 & $0.460^{\mathrm{c}}$ & 98 & 5.365 & 45 & 0.828 & 3.282 & -0 . & -4 & 2.083 & & 3.287 \\
\hline $\mathrm{CNP}$ & .730 & $0.993^{\mathrm{a}}$ & 3.694 & 3.268 & $-0.066^{b}$ & -1.778 & 9.461 & $1.059^{\mathrm{a}}$ & 3.786 & 5.485 & $0.165^{\mathrm{a}}$ & 2.968 & 3.373 & $-0.064^{b}$ & -2.040 & 2.112 & $0.229^{\mathrm{a}}$ & 3.589 \\
\hline CPI & .040 & $1.303^{\mathrm{a}}$ & 3.209 & 3.105 & $-0.230^{\mathrm{a}}$ & -4.894 & 9.935 & $1.533^{\mathrm{a}}$ & 3.670 & 5.366 & 046 & 0.593 & 3.227 & $-0.210^{\mathrm{a}}$ & 84 & & & 2.951 \\
\hline $\mathrm{CS}$ & 919 & 0.182 & 0.698 & 3.464 & $0.130^{\mathrm{a}}$ & 3.457 & 8.454 & 0.052 & 0.191 & 5.353 & 0.033 & 0.737 & 3.572 & $0.135^{\mathrm{a}}$ & 4.286 & 1.781 & $-0.102^{b}$ & -1.891 \\
\hline $\mathrm{CU}$ & & & 5.958 & 3.250 & & -2.053 & & $2.007^{\mathrm{a}}$ & & & & 01 & 3. & & -3 . & 2.330 & & 5.986 \\
\hline $\mathrm{FO}$ & .438 & $0.701^{\mathrm{b}}$ & 2.304 & 3.185 & $-0.150^{\mathrm{a}}$ & -3.465 & 9.253 & $0.851^{\mathrm{a}}$ & 2.692 & 5.472 & $0.152^{\mathrm{a}}$ & 2.541 & 3.288 & $-0.149^{\mathrm{a}}$ & -4.167 & 2.184 & $0.301^{\mathrm{a}}$ & 4.320 \\
\hline FOM & 3.143 & $11.406^{\mathrm{a}}$ & 4.837 & 3.180 & -0.155 & -0.909 & 19.963 & $11.561^{\mathrm{a}}$ & 4.676 & 6.290 & $0.970^{\mathrm{a}}$ & 7.093 & 2.931 & $-0.506^{\mathrm{a}}$ & -3 & 3.360 & $1.476^{\mathrm{a}}$ & 6.462 \\
\hline GDP & 216 & $-0.521^{b}$ & -2.160 & 3.598 & $0.263^{\mathrm{a}}$ & 6.909 & 7.618 & $-0.784^{\mathrm{a}}$ & -3.131 & 5.359 & 39 & 0.698 & 3.685 & $0.248^{\mathrm{a}}$ & 90 & 1.675 & -0.2 & -3.307 \\
\hline HS & 972 & & 1.222 & 3.324 & & -0.387 & 8.649 & 0.247 & 1.235 & 5.370 & 0. & 90 & 3.435 & & -0 . & 1.9 & & 1.181 \\
\hline IP & 531 & & 2.850 & 3.488 & & 3.769 & 9.043 & $0.641^{b}$ & 2.188 & 5.578 & & 79 & 3.568 & & & 2.011 & & 1.728 \\
\hline NAP & .316 & $0.579^{\mathrm{b}}$ & 1.939 & 3.583 & $0.248^{\mathrm{a}}$ & 6.195 & 8.732 & & 1.061 & 5.531 & $0.211^{\mathrm{a}}$ & 2.486 & 3.618 & $0.182^{\mathrm{a}}$ & 5.366 & 1.913 & & 0.318 \\
\hline NHS & 2.163 & $0.426^{\mathrm{c}}$ & 1.635 & 3.209 & $-0.126^{\mathrm{a}}$ & -3.453 & 8.954 & $0.552^{b}$ & 2.054 & 5.333 & & 0.274 & 3.325 & $-0.112^{\mathrm{a}}$ & -3.723 & 2.008 & $0.125^{\mathrm{a}}$ & 2.342 \\
\hline PI & 1.681 & -0.056 & -0.187 & 3.240 & $-0.094^{b}$ & -2.105 & 8.440 & 0.038 & 0.124 & 5.227 & $-0.093^{b}$ & -1.947 & 3.356 & $-0.081^{b}$ & -2.185 & 1.872 & -0.012 & -0.225 \\
\hline PPI & .692 & $0.955^{\mathrm{a}}$ & 2.941 & 3.236 & $-0.099^{b}$ & -2.261 & 9.456 & $1.053^{\mathrm{a}}$ & 3.126 & 5.418 & $0.098^{\mathrm{b}}$ & 1.802 & 3.345 & $-0.091^{\mathrm{a}}$ & -2.547 & 2.073 & $0.190^{\mathrm{a}}$ & 2.999 \\
\hline TBGS & 223 & $0.486^{\mathrm{c}}$ & 1.522 & 3.308 & -0.026 & -0.636 & 8.914 & $0.512^{\mathrm{c}}$ & 1.560 & 5.421 & $0.101^{\mathrm{c}}$ & 1.369 & 3.414 & -0.022 & -0.644 & 2.006 & $3^{c}$ & 1.531 \\
\hline UR & 3.590 & $1.853^{\mathrm{a}}$ & 5.433 & 2.920 & $-0.415^{\mathrm{a}}$ & -8.244 & 10.670 & $2.268^{\mathrm{a}}$ & 6.373 & 5.615 & $0.295^{\mathrm{a}}$ & 4.447 & 3.134 & $-0.303^{\mathrm{a}}$ & -7.361 & 2.482 & $0.598^{\mathrm{a}}$ & 7.844 \\
\hline No-News & 11.737 & & & 3.335 & & & 8.402 & & & 5.320 & & & 3.437 & & & 1.883 & & \\
\hline
\end{tabular}




\section{EXHIBIT 6}

\section{Regression Results}

\begin{tabular}{|c|c|c|c|c|c|c|c|c|}
\hline \multirow{3}{*}{ Variables } & & & \multicolumn{6}{|c|}{ Investment Grade } \\
\hline & \multicolumn{2}{|c|}{ High-Yield Bonds } & \multicolumn{2}{|c|}{ Treasury } & \multicolumn{2}{|c|}{ Bonds } & \multicolumn{2}{|c|}{ Treasury } \\
\hline & Coefficient & T-stat & Coefficient & T-stat & Coefficient & T-stat & Coefficient & T-stat \\
\hline $\mathrm{C}$ & $11.977^{\mathrm{a}}$ & 220.069 & $3.317^{\mathrm{a}}$ & 406.367 & $5.398^{\mathrm{a}}$ & 460.195 & $3.436^{\mathrm{a}}$ & 507.162 \\
\hline Advanced Retail Sales (ARS) & $-0.771^{\mathrm{a}}$ & -4.126 & $0.050^{\mathrm{c}}$ & 1.797 & $-0.188^{\mathrm{a}}$ & -4.727 & 0.036 & 1.583 \\
\hline Business Inventories (BI) & $-1.350^{\mathrm{a}}$ & -7.293 & $0.169^{\mathrm{a}}$ & 6.079 & $-0.199^{\mathrm{a}}$ & -5.080 & $0.155^{\mathrm{a}}$ & 6.844 \\
\hline Treasury Budget Statement (BST) & $-0.944^{\mathrm{a}}$ & -4.845 & $0.143^{\mathrm{a}}$ & 4.901 & -0.042 & -1.025 & $0.113^{\mathrm{a}}$ & 4.754 \\
\hline Capacity Utilization (CU) & $-0.722^{\mathrm{a}}$ & -3.916 & $0.202^{\mathrm{a}}$ & 7.289 & -0.064 & -1.637 & $0.174^{\mathrm{a}}$ & 7.680 \\
\hline Change in Nonfarm Payrolls (CNP) & $-1.176^{\mathrm{a}}$ & -6.290 & -0.003 & -0.118 & $-0.159^{a}$ & -4.053 & $0.041^{\mathrm{c}}$ & 1.813 \\
\hline Construction Spending (CS) & $-0.670^{\mathrm{a}}$ & -3.670 & $0.163^{\mathrm{a}}$ & 5.939 & -0.026 & -0.651 & $0.161^{\mathrm{a}}$ & 6.964 \\
\hline Consumer Confidence (CC) & -0.143 & -0.778 & $-0.433^{\mathrm{a}}$ & -15.741 & -0.044 & -1.139 & $-0.334^{\mathrm{a}}$ & -14.960 \\
\hline Consumer Price Index (CPI) & $-3.396^{\mathrm{a}}$ & -10.654 & 0.055 & 1.160 & $-0.588^{\mathrm{a}}$ & -8.829 & $0.168^{\mathrm{a}}$ & 4.359 \\
\hline Factory Orders (FO) & $-0.717^{\mathrm{a}}$ & -3.919 & $0.058^{\mathrm{b}}$ & 2.106 & $-0.168^{\mathrm{a}}$ & -4.314 & $0.077^{\mathrm{a}}$ & 3.408 \\
\hline Federal Open Market Committee (FOMC) & $-1.351^{\mathrm{a}}$ & -5.741 & $-0.162^{\mathrm{a}}$ & -4.587 & $-0.086^{\mathrm{c}}$ & -1.780 & $-0.054^{\mathrm{c}}$ & -1.951 \\
\hline Gross Domestic Product (GDP) & -0.242 & -1.332 & $-0.198^{\mathrm{a}}$ & -7.247 & -0.063 & -1.621 & $-0.145^{\mathrm{a}}$ & -6.406 \\
\hline Housing Starts (HS) & $-0.499^{\mathrm{a}}$ & -2.764 & $0.129^{\mathrm{a}}$ & 4.760 & $-0.124^{\mathrm{a}}$ & -3.183 & $0.122^{\mathrm{a}}$ & 5.448 \\
\hline Industrial Production (IP) & $1.313^{\mathrm{a}}$ & 4.043 & -0.023 & -0.471 & $0.113^{\mathrm{c}}$ & 1.685 & $-0.119^{a}$ & -3.083 \\
\hline NAPM & $-1.030^{\mathrm{a}}$ & -5.735 & $-0.206^{\mathrm{a}}$ & -7.636 & $-0.380^{\mathrm{a}}$ & -9.722 & $-0.148^{\mathrm{a}}$ & -6.544 \\
\hline New Home Sales (NHS) & 0.117 & 0.655 & $0.136^{\mathrm{a}}$ & 5.091 & -0.022 & -0.568 & $0.123^{\mathrm{a}}$ & 5.455 \\
\hline Personal Income (PI) & $0.809^{\mathrm{a}}$ & 4.629 & -0.032 & -1.206 & $0.177^{\mathrm{a}}$ & 4.639 & -0.001 & -0.044 \\
\hline Producer Price Index (PPI) & $-0.652^{\mathrm{a}}$ & -3.514 & $0.084^{\mathrm{a}}$ & 3.025 & $-0.079^{b}$ & -1.980 & $0.078^{\mathrm{a}}$ & 3.388 \\
\hline Trade Balance Goods and Services (TBGS) & 0.159 & 0.855 & -0.021 & -0.769 & $0.154^{\mathrm{a}}$ & 3.961 & -0.011 & -0.480 \\
\hline Unemployment Rate (UR) & $-1.376^{\mathrm{a}}$ & -7.248 & $0.143^{\mathrm{a}}$ & 5.030 & $-0.242^{\mathrm{a}}$ & -5.973 & $0.119^{\mathrm{a}}$ & 5.102 \\
\hline $\operatorname{Adj}-R^{2}$ & \multicolumn{2}{|c|}{$1.384 \%$} & \multicolumn{2}{|c|}{$1.657 \%$} & \multicolumn{2}{|c|}{$1.075 \%$} & \multicolumn{2}{|c|}{$1.554 \%$} \\
\hline
\end{tabular}

Notes: This table reports the regression with the following form: $Y_{G, t}=c+\sum_{i=1}^{19} c_{i} S A_{i, t}+\varepsilon_{G, t}$, where, $Y_{G, t}$ refers to the bond yield at time $t$, for bond class I or J, and the corresponding points on the Treasury yield curve. 


\section{EXHIBIT 7}

\section{Pooled Regression with Dummies}

\begin{tabular}{|c|c|c|c|c|c|c|}
\hline \multirow[t]{2}{*}{ Variables } & \multicolumn{2}{|c|}{ *DJ } & \multicolumn{2}{|c|}{ *DI } & \multicolumn{2}{|c|}{$\begin{array}{l}\text { Wald Test of Equality of } \\
\text { Absolute Coefficients }\end{array}$} \\
\hline & Coefficient & T-stat & Coefficient & T-stat & Difference & Chi-square \\
\hline $\mathrm{C}$ & $8.660^{\mathrm{a}}$ & 214.277 & $1.962^{\mathrm{a}}$ & 50.403 & $6.698^{\mathrm{a}}$ & 14247 \\
\hline Advanced Retail Sales (ARS) & $-0.821^{\mathrm{a}}$ & -5.919 & $-0.224^{\mathrm{c}}$ & -1.700 & $0.597^{\mathrm{a}}$ & 9.731 \\
\hline Business Inventories (BI) & $-1.519^{\mathrm{a}}$ & -11.050 & $-0.354^{\mathrm{a}}$ & -2.722 & $1.165^{\mathrm{a}}$ & 37.816 \\
\hline Treasury Budget Statement (BST) & $-1.087^{\mathrm{a}}$ & -7.515 & -0.156 & -1.136 & $0.932^{\mathrm{a}}$ & 21.849 \\
\hline Capacity Utilization (CU) & $-0.924^{\mathrm{a}}$ & -6.746 & $-0.238^{\mathrm{c}}$ & -1.830 & $0.686^{\mathrm{a}}$ & 13.180 \\
\hline Change in Nonfarm Payrolls (CNP) & $-1.172^{\mathrm{a}}$ & -8.447 & -0.200 & -1.537 & $0.972^{\mathrm{a}}$ & 26.127 \\
\hline Construction Spending (CS) & $-0.833^{\mathrm{a}}$ & -6.142 & -0.187 & -1.408 & $0.646^{\mathrm{a}}$ & 11.576 \\
\hline Consumer Confidence (CC) & $0.290^{\mathrm{b}}$ & 2.132 & $0.290^{\mathrm{b}}$ & 2.260 & 0.000 & 0.000 \\
\hline Consumer Price Index (CPI) & $-3.451^{\mathrm{a}}$ & -14.582 & $-0.756^{\mathrm{a}}$ & -3.419 & $2.696^{\mathrm{a}}$ & 69.297 \\
\hline Factory Orders (FO) & $-0.774^{\mathrm{a}}$ & -5.703 & $-0.245^{\mathrm{c}}$ & -1.893 & $0.529^{\mathrm{a}}$ & 7.942 \\
\hline $\begin{array}{l}\text { Federal Open Market Committee } \\
\text { (FOMC) }\end{array}$ & $-1.189^{\mathrm{a}}$ & -6.805 & -0.031 & -0.197 & $1.157^{\mathrm{a}}$ & 23.923 \\
\hline Gross Domestic Product (GDP) & -0.044 & -0.330 & 0.081 & 0.626 & -0.037 & 0.039 \\
\hline Housing Starts (HS) & $-0.628^{a}$ & -4.684 & $-0.246^{\mathrm{c}}$ & -1.907 & $0.382^{b}$ & 4.215 \\
\hline Industrial Production (IP) & $1.336^{\mathrm{a}}$ & 5.540 & 0.232 & 1.044 & $1.104^{\mathrm{a}}$ & 11.360 \\
\hline NAPM & $-0.824^{\mathrm{a}}$ & -6.181 & $-0.232^{\mathrm{c}}$ & -1.790 & $0.592^{\mathrm{a}}$ & 10.109 \\
\hline New Home Sales (NHS) & -0.019 & -0.146 & -0.146 & -1.121 & -0.126 & 0.463 \\
\hline Personal Income (PI) & $0.841^{\mathrm{a}}$ & 6.478 & 0.178 & 1.406 & $0.663^{\mathrm{a}}$ & 13.405 \\
\hline Producer Price Index (PPI) & $-0.737^{\mathrm{a}}$ & -5.343 & -0.156 & -1.186 & $0.581^{\mathrm{a}}$ & 9.280 \\
\hline Trade Balance Goods and $\mathrm{Se}$ & & & & & & \\
\hline (TBGS) & 0.180 & 1.306 & 0.165 & 1.277 & 0.015 & 0.006 \\
\hline Unemployment Rate (UR) & $-1.519^{\mathrm{a}}$ & -10.778 & $-0.362^{\mathrm{a}}$ & -2.688 & $1.157^{\mathrm{a}}$ & 35.297 \\
\hline Adj- $R^{2}$ & & & 17.86 & & & \\
\hline
\end{tabular}

Notes: This table reports results from regression with the following form: $Y S_{t}=b_{J} D J+b_{I} D I+\sum_{i=1}^{19} c_{J, i} S A_{i, t} D I+$ $\sum_{i=1}^{19} c_{I, i} S A_{i, t} D J+\varepsilon_{t}$.

\{Are we suppressing the constant?\} (Hong: No. They are the B(J) and B(i) ) 


\section{EXHIBIT 8}

\section{Pooled Regression with Dummies and Control Variables}

\begin{tabular}{|c|c|c|c|c|c|c|}
\hline \multirow[t]{2}{*}{ Variables } & \multicolumn{2}{|c|}{ *DJ } & \multicolumn{2}{|c|}{ *DI } & \multicolumn{2}{|c|}{$\begin{array}{l}\text { Wald Test of Equality of } \\
\text { Absolute Coefficients }\end{array}$} \\
\hline & Coefficient & T-stat & Coefficient & T-stat & Difference & Chi-square \\
\hline $\mathrm{C}$ & $11.689^{\mathrm{a}}$ & 70.964 & $3.018^{\mathrm{a}}$ & 12.457 & $8.671^{\mathrm{a}}$ & 876.097 \\
\hline Rindex & $-5.915^{\mathrm{a}}$ & -88.014 & $-0.987^{\mathrm{a}}$ & -16.116 & $4.928^{\mathrm{a}}$ & 2936.367 \\
\hline Duration & $-1.154^{\mathrm{a}}$ & -33.939 & $-0.121^{\mathrm{a}}$ & -4.783 & $1.034^{\mathrm{a}}$ & 596.017 \\
\hline Convexity & $0.040^{\mathrm{a}}$ & 20.148 & $0.004^{\mathrm{a}}$ & 3.445 & $0.036^{\mathrm{a}}$ & 232.626 \\
\hline Quality Yield & $8.090^{\mathrm{a}}$ & 149.710 & $2.141^{\mathrm{a}}$ & 45.965 & $5.949^{\mathrm{a}}$ & 6951.963 \\
\hline Advanced Retail Sales (ARS) & 0.170 & 1.581 & 0.026 & 0.258 & 0.144 & 0.939 \\
\hline Business Inventories (BI) & $-0.436^{\mathrm{a}}$ & -4.088 & 0.011 & 0.108 & $0.425^{\mathrm{a}}$ & 8.365 \\
\hline Treasury Budget Statement (BST) & $-0.717^{\mathrm{a}}$ & -6.402 & -0.045 & -0.422 & $0.672^{\mathrm{a}}$ & 18.988 \\
\hline Capacity Utilization (CU) & -0.023 & -0.215 & -0.060 & -0.594 & -0.037 & 0.064 \\
\hline Change in Nonfarm Payrolls (CNP) & $-0.582^{\mathrm{a}}$ & -5.421 & -0.053 & -0.523 & $0.530^{\mathrm{a}}$ & 12.941 \\
\hline Construction Spending (CS) & $-0.484^{\mathrm{a}}$ & -4.616 & 0.009 & 0.083 & $0.476^{\mathrm{a}}$ & 10.492 \\
\hline Consumer Confidence (CC) & $-0.696^{\mathrm{a}}$ & -6.595 & 0.020 & 0.204 & $0.676^{\mathrm{a}}$ & 21.704 \\
\hline Consumer Price Index (CPI) & $-0.884^{\mathrm{a}}$ & -4.811 & -0.027 & -0.157 & $0.857^{\mathrm{a}}$ & 11.607 \\
\hline Factory Orders (FO) & $0.303^{\mathrm{a}}$ & 2.876 & 0.092 & 0.911 & 0.211 & 2.105 \\
\hline \multicolumn{7}{|l|}{ Federal Open Market Committee } \\
\hline Gross Domestic Product (GDP) & $-0.359^{\mathrm{a}}$ & -3.434 & -0.005 & -0.048 & $0.354^{\mathrm{b}}$ & 5.968 \\
\hline Housing Starts (HS) & 0.016 & 0.153 & -0.044 & -0.438 & -0.028 & 0.037 \\
\hline Industrial Production (IP) & 0.197 & 1.055 & -0.139 & -0.810 & 0.058 & 0.052 \\
\hline NAPM & $-0.547^{\mathrm{a}}$ & -5.295 & $-0.190^{c}$ & -1.891 & $0.357^{\mathrm{b}}$ & 6.127 \\
\hline New Home Sales (NHS) & $0.434^{\mathrm{a}}$ & 4.240 & -0.053 & -0.531 & $0.381^{\mathrm{a}}$ & 7.049 \\
\hline Personal Income (PI) & -0.144 & -1.431 & -0.010 & -0.103 & 0.134 & 0.909 \\
\hline Producer Price Index (PPI) & $-0.230^{\mathrm{b}}$ & -2.159 & 0.023 & 0.222 & 0.208 & 1.984 \\
\hline \multicolumn{7}{|l|}{ Trade Balance Goods and Services } \\
\hline Unemployment Rate (UR) & $-0.335^{\mathrm{a}}$ & -3.065 & -0.019 & -0.183 & $0.316^{\mathrm{b}}$ & 4.374 \\
\hline Adj-R ${ }^{2}$ & & & & $803 \%$ & 0.510 & \\
\hline \multicolumn{7}{|c|}{$\begin{array}{l}\text { Notes: This table reports the simple regression with the following form: } \\
Y S_{t}= \\
b_{J} D J+c_{J, 1} \text { Rindex }_{t} D J+c_{J, 2} \text { Duration }_{t} D J+c_{J, 3} \text { Convexity }_{t} D J+c_{J, 4} \text { QualityYield }_{t} D J+\sum_{i=1}^{19} d_{J, i} S A_{i, t} D J+b_{I} D I+ \\
c_{I, 1} \text { Rindex }_{t} D I+c_{I, 2} \text { Duration }_{t} D I+c_{I, 3} \text { Convexity }_{t} D I+c_{I, 4} \text { QualityYeld }_{t} D I+\sum_{i=1}^{19} d_{I, i} A_{i, t} D I+\varepsilon_{t} .\end{array}$} \\
\hline
\end{tabular}




\section{EXHIBIT 9}

\section{RESUlTS OF ASYMMETRIC REGRESSIONS}

Panel A: High-yield Bonds

\begin{tabular}{|c|c|c|c|c|c|c|}
\hline \multirow[t]{2}{*}{ Variables } & \multicolumn{2}{|c|}{$c_{i}^{+}$} & \multicolumn{2}{|l|}{$c_{i}^{-}$} & \multicolumn{2}{|c|}{$\begin{array}{c}\text { Wald Test of Equality } \\
\text { of Absolute Est. }\end{array}$} \\
\hline & Coefficient & T-stat & Coefficient & T-stat & Difference & Chi-square \\
\hline $\mathrm{C}$ & $7.993^{\mathrm{a}}$ & 91.158 & & & & \\
\hline Advanced Retail Sales (ARS) & 0.236 & 0.765 & $-1.899^{\mathrm{a}}$ & -6.255 & $-1.663^{\mathrm{a}}$ & 18.538 \\
\hline Business Inventories (BI) & $-1.041^{\mathrm{a}}$ & -3.202 & $-2.122^{\mathrm{a}}$ & -7.385 & $-1.081^{b}$ & 5.155 \\
\hline Treasury Budget Statement (BST) & -0.015 & -0.051 & $-2.309^{\mathrm{a}}$ & -7.781 & $-2.294^{\mathrm{a}}$ & 29.225 \\
\hline Capacity Utilization (CU) & $-0.832^{\mathrm{a}}$ & -3.397 & 0.315 & 0.862 & 0.517 & 0.873 \\
\hline Change in Nonfarm Payrolls (CNP) & $-0.607^{\mathrm{c}}$ & -1.799 & $-1.824^{\mathrm{a}}$ & -6.314 & $-1.217^{b}$ & 6.301 \\
\hline Construction Spending (CS) & 0.195 & 0.691 & $-1.801^{\mathrm{a}}$ & -6.338 & $-1.606^{\mathrm{a}}$ & 17.547 \\
\hline Consumer Confidence (CC) & $0.706^{\mathrm{a}}$ & 2.848 & -0.378 & -1.046 & 0.328 & 0.649 \\
\hline Consumer Price Index (CPI) & $-4.935^{\mathrm{a}}$ & -10.010 & -0.614 & -1.093 & $4.321^{\mathrm{a}}$ & 28.230 \\
\hline Factory Orders (FO) & $0.811^{\mathrm{a}}$ & 2.837 & $-2.201^{\mathrm{a}}$ & -8.255 & $-1.390^{\mathrm{a}}$ & 13.365 \\
\hline Federal Open Market Committee & & 5876 & & -7529 & $2613^{\mathrm{a}}$ & 9797 \\
\hline $\begin{array}{l}\text { (FOMC) } \\
\text { Gross Domestic Product (GDP) }\end{array}$ & $\begin{array}{l}4.645^{\mathrm{a}} \\
1.610^{\mathrm{a}}\end{array}$ & $\begin{array}{l}5.8 / 6 \\
5.453\end{array}$ & $\begin{array}{l}-2.031^{4} \\
-0.449\end{array}$ & $\begin{array}{l}-1.329 \\
-1.594\end{array}$ & $\begin{array}{l}2.013 \\
1.161^{\mathrm{a}}\end{array}$ & 8.446 \\
\hline Housing Starts (HS) & -0.257 & -1.148 & $0.714^{\mathrm{b}}$ & 2.101 & -0.457 & 0.833 \\
\hline Industrial Production (IP) & $5.410^{\mathrm{a}}$ & 10.427 & $-2.368^{\mathrm{a}}$ & -4.286 & $3.042^{\mathrm{a}}$ & 19.420 \\
\hline NAPM & $-0.500^{\mathrm{c}}$ & -1.893 & $-1.446^{\mathrm{a}}$ & -4.639 & $-0.946^{\mathrm{b}}$ & 4.750 \\
\hline New Home Sales (NHS) & $-0.619^{b}$ & -2.532 & $0.860^{\mathrm{a}}$ & 2.874 & -0.241 & 0.401 \\
\hline Personal Income (PI) & $1.087^{\mathrm{a}}$ & 5.455 & -0.255 & -0.511 & 0.832 & 2.474 \\
\hline Producer Price Index (PPI) & $-0.897^{\mathrm{a}}$ & -3.550 & -0.043 & -0.137 & $0.853^{\mathrm{b}}$ & 4.216 \\
\hline $\begin{array}{l}\text { Trade Balance Goods and Services } \\
\text { (TBGS) }\end{array}$ & $0.943^{\mathrm{a}}$ & 3.647 & $-0.627^{b}$ & -1.989 & 0.316 & 0.649 \\
\hline Unemployment Rate (UR) & $-1.653^{\mathrm{a}}$ & -6.130 & $-1.812^{\mathrm{a}}$ & -4.981 & -0.159 & 0.105 \\
\hline Adj- $R^{2}$ & & & 2.52 & & & \\
\hline
\end{tabular}

Notes: This table reports the simple regression with the following form: $Y S_{G, t}=c+\sum_{i=1}^{19} c_{i}^{+} S A_{i, t}^{+}+\sum_{i=1}^{19} c_{i}^{-} S A_{i, t}^{-}+$ $\varepsilon_{G, t}, G=I$ or J. where, $Y S_{G, t}$ refers to the bond yield-spread at time $t$, for bond class I or J. 
Panel B: Investment Grade Bonds

\begin{tabular}{|c|c|c|c|c|c|c|}
\hline \multirow{2}{*}{ Variables } & \multicolumn{2}{|c|}{$c_{i}^{+}$} & \multicolumn{2}{|c|}{$c_{i}^{-}$} & \multicolumn{2}{|c|}{$\begin{array}{c}\text { Wald Test of Equality } \\
\text { of Absolute Est. }\end{array}$} \\
\hline & Est. & T-stat & Est. & T-stat & Diff. & Chi-square \\
\hline $\mathrm{C}$ & $1.810^{\mathrm{a}}$ & 88.926 & & & & \\
\hline Advanced Retail Sales (ARS) & $0.183^{\mathrm{b}}$ & 2.560 & $-0.617^{\mathrm{a}}$ & -8.965 & $-0.433^{\mathrm{a}}$ & 24.034 \\
\hline Business Inventories (BI) & $-0.453^{\mathrm{a}}$ & -6.130 & $-0.293^{\mathrm{a}}$ & -4.419 & 0.160 & 2.143 \\
\hline Treasury Budget Statement (BST) & 0.021 & 0.310 & $-0.332^{\mathrm{a}}$ & -5.108 & $-0.311^{\mathrm{a}}$ & 11.309 \\
\hline Capacity Utilization (CU) & $-0.164^{\mathrm{a}}$ & -2.948 & $0.190^{\mathrm{b}}$ & 2.257 & -0.026 & 0.041 \\
\hline Change in Nonfarm Payrolls (CNP) & $-0.155^{\mathrm{b}}$ & -2.029 & $-0.264^{\mathrm{a}}$ & -4.059 & -0.108 & 0.972 \\
\hline Construction Spending (CS) & $-0.117^{\mathrm{c}}$ & -1.738 & $-0.173^{\mathrm{a}}$ & -2.633 & -0.056 & 0.329 \\
\hline Consumer Confidence (CC) & $0.410^{\mathrm{a}}$ & 7.349 & 0.073 & 0.864 & $0.338^{\mathrm{a}}$ & 9.845 \\
\hline Consumer Price Index (CPI) & $-0.925^{\mathrm{a}}$ & -8.422 & -0.214 & -1.634 & $0.711^{\mathrm{a}}$ & 14.587 \\
\hline Factory Orders (FO) & $0.193^{\mathrm{a}}$ & 2.875 & $-0.617^{\mathrm{a}}$ & -10.254 & $-0.424^{\mathrm{a}}$ & 23.458 \\
\hline Federal Open Market Committee (FOMC) & $1.080^{\mathrm{a}}$ & 6.043 & $-0.230^{\mathrm{a}}$ & -3.878 & $0.850^{\mathrm{a}}$ & 20.375 \\
\hline Gross Domestic Product (GDP) & $0.484^{\mathrm{a}}$ & 7.203 & -0.066 & -0.991 & $0.418^{\mathrm{a}}$ & 20.332 \\
\hline Housing Starts (HS) & $-0.090^{c}$ & -1.740 & $0.358^{\mathrm{a}}$ & 4.572 & $-0.268^{\mathrm{b}}$ & 5.453 \\
\hline Industrial Production (IP) & $0.938^{\mathrm{a}}$ & 8.314 & $-0.490^{\mathrm{a}}$ & -3.847 & $0.448^{\mathrm{a}}$ & 8.481 \\
\hline NAPM & -0.052 & -0.842 & $-0.546^{\mathrm{a}}$ & -7.518 & $-0.493^{\mathrm{a}}$ & 23.628 \\
\hline New Home Sales (NHS) & $-0.385^{\mathrm{a}}$ & -6.666 & $0.172^{\mathrm{b}}$ & 2.445 & $0.214^{\mathrm{b}}$ & 5.682 \\
\hline Personal Income (PI) & $0.188^{\mathrm{a}}$ & 4.017 & 0.161 & 1.379 & 0.027 & 0.046 \\
\hline Producer Price Index (PPI) & $-0.203^{\mathrm{a}}$ & -3.460 & -0.005 & -0.067 & $0.198^{\mathrm{b}}$ & 4.358 \\
\hline Trade Balance Goods and Services (TBGS) & $0.342^{\mathrm{a}}$ & 5.875 & -0.041 & -0.584 & $0.301^{\mathrm{a}}$ & 11.626 \\
\hline Unemployment Rate (UR) & $-0.465^{\mathrm{a}}$ & -7.515 & $-0.314^{\mathrm{a}}$ & -3.745 & 0.151 & 1.785 \\
\hline $\operatorname{Adj}-R^{2}$ & & & & $2.581 \%$ & & \\
\hline
\end{tabular}

Notes: This table reports the simple regression with the following form: $Y S_{G, t}=c+\sum_{i=1}^{19} c_{i}^{+} S A_{i, t}^{+}+\sum_{i=1}^{19} c_{i}^{-} S A_{i, t}^{-}+$ $\varepsilon_{G, t}, G=I$ or J. where, $Y S_{G, t}$ refers to the bond yield-spread at time $t$, for bond class I or J. 